\title{
CAREER CHOICE MOTIVATION OF HIGH SCHOOL STUDENTS IN CONTEXT OF CHANGING HIGHER EDUCATION IN KNOWLEDGE ECONOMY*
}

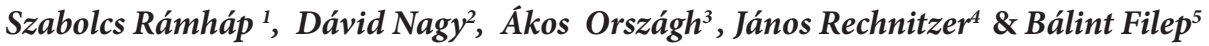 \\ UDC/UDK: 331.101.3:373.5-057.875(439) \\ JEL classification / JEL klasifikacija: I23, I25 \\ DOI: https://doi.org/10.22598/pi-be/2017.11.2.23 \\ Preliminary communication / Prethodno priopćenje \\ Received / Primljeno: September 28, 2017 / 28. rujna 2017. \\ Accepted for publication / Prihvaćeno za tisak: November 27, 2017 / 27. studenoga 2017.
}

\section{Summary}

The 21st century came with drastic social and economic changes bringing about the era of the knowledge economy. With increased significance of knowledge, there was a change in its nature and the expectations towards it. The traditional approach both in secondary and higher education is not capable of satisfying the needs of qualified trainings in strategic industries. Education institutes dealing with knowledge creation, exploitation, dissemination and reproduction have become the grounds of the knowledge based society. Today the role and tasks of higher education institutions are re-evaluated across Europe, which will lead to new approaches in economic and social roles and projects. Universities make a fundamental contribution to the reproduction and adaptation of human resources, and their importance is growing among regional actors. The part that higher education institutes play in supporting regional governance is widely respected.

\footnotetext{
The paper was presented at the 2nd International Conference „Business \& Entrepreneurial Economics -BEE2017” which was held in Brijuni from 24 to 26 May 2017 (www.bee-conference.com)

1 Szabolcs Rámháp, Ph.D. Candidate, Széchenyi István University, Doctoral School of Regional-and Economic Sciences, Győr, Hungary, E-mail: ramhap@sze.hu

2 Dávid Nagy, Ph.D. Student, Széchenyi István University, Doctoral School of Regional-and Economic Sciences, Győr, Hungary, E-mail: nagy.david@ga.sze.hu

3 Ákos Országh, Ph.D. Student, Széchenyi István University, Doctoral School of Regional-and Economic Sciences, Győr, Hungary, E-mail: orszakos@gmail.com

4 János Rechnitzer, Doctoral Thesis Supervisor, Professor and Head of Department, Department of Regional Studies and Public Policy, Széchenyi István University, Győr, Hungary, E-mail: rechnj@sze.hu

5 Bálint Filep, Doctoral Thesis Supervisor, Associate Professor, Department of Regional Studies and Public Policy, Széchenyi István University, Győr, Hungary, E-mail: filep.balint@sze.hu
} 
Our research focuses on career motivation of high school students in North-Transdanubia region of Hungary, which is the most important industrial basis of the country, the centre of the Hungarian vehicle industry. The paper is based on a survey conducted among 2000 respondents. Their personal motivation determine the survival of higher education institutions in the circumstances of increasing competition, and they have an influence on improving regional competitiveness. The research used some statistical methods such as frequencies, means, cross-tables, ANOVA, factor and cluster analysis.

The main goal of the research is to highlight the connection between higher education and regional economy through the example of the industrial district of Gyor and to demonstrate how quality industry in the knowledge economy can influence the career motivation of youngsters in the field of choosing their future education area, and how they can imagine their employment opportunities and expected income in the labour market in the future, or whether they would choose to move abroad.

Key words: career choice motivation, high school students, knowledge economy, North Transdanubia region, Hungary.

\section{THE BACKGROUND AND SIGNIFICANCE OF THE RESEARCH}

The development of the knowledge economy resulted in drastic changes in the tertiary education system. Martin Trow (2000) examined the problem of transition from elite to mass higher education, and he came to the conclusion that the era of elite higher education is over when the participation rate exceeds $15 \%$. The participation in the mass system is up to $50 \%$, and universal higher education means that half of the population or more of the relevant age group participate in it. In mass higher education system, the conditions of entry, the teaching methods, the methods of examination and the qualification methods have decisively changed. But there are also changes in the motivation of students, in the recruitment of lecturers, socialisation, standards and compliance with them, moral questions, students' behaviour, job search support, financing, governance and the administration of institutions, and in the relationship with secondary education. According to Ildikó Hrubos (2014) the expansion of higher education in the USA started in the 1950s, in Europe a decade later, but in Hungary only after the regime change in 1990.

As far as the function of higher education institutions is concerned, Clark (1998) defined three traditional university models in the 19th and 20th century: 1) traditional British model 2) Continental model which is based on a strong governmental role 3) American model which relies on competition and trainings in a wide a range. In these traditional university models, higher education institutions have a dual role: 'on the one hand they fulfil their educational tasks as their main activity, on the other hand they also participate in research. The key factor why this dual role was developed is that research and education can exist side by side on a more cost-effective level because of their synergistic effect.' In connection with the pretty new needs of the knowledge economy, universities in the 21st century have to take on not only the main issues mentioned above such as research and education, but other tasks as well. 
By Entrepreneurial University we mean the new generation of higher education institutions with a third mission: community engagement. Etzkowitz and Leydesdorff (2000) created the Triple Helix concept to model the relationship of university, industry and government. Carayannis and Campbell (2012) created the Quadruple Helix by rethinking the Triple Helix model, in which the media and culture-based community space and civil society constitute the forth helix. In the same year, Campbell (2012) introduced the fifth helix in Quintuple Helix model by placing the challenges of global warming in the focus of the analysis.

According to the new function of Higher Education Institutions, based on Lengyel's (2004) regional competitiveness model, Filep et al. (2010) created the higher education competitiveness model (Figure 1.). Several examples show that today the question of competitiveness is also present in higher education and not just enterprises and nations. There is competition for students, teachers, as well as for material resources for R\&D\&I work and training.

Figure 1: The competitiveness model of higher educational institutes (Filep et al, 2010)

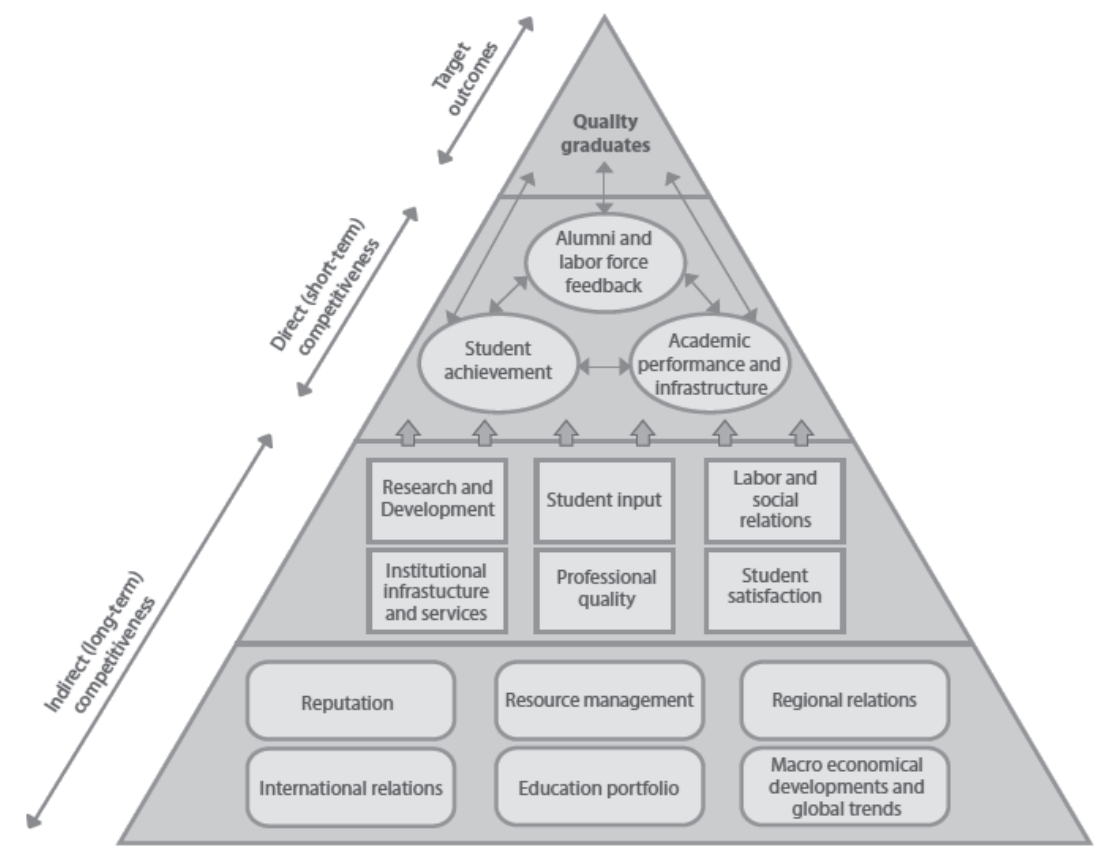

\section{CAREER CHOICE AS A CONSUMER DECISION IN MARKETING}

As part of the education system, higher education belongs to public services. In our world of globalisation, the emergence of a knowledge-based society means that the role of higher education system is transforming; it has to successfully respond to chang- 
es and challenges as organisations in the business field do the same. In their search for proper solutions and answers they use those kinds of management techniques that have so far been typical for the for-profit sector. When universities and colleges began to apply these new techniques and methods in the 1950s, a new and young discipline appeared which dealt with the management of higher education institutions (Barakonyi, 2010).

Competition in higher education has become more and more typical as well, bringing success and competition of these institutes under the spotlight. Institutions of the public sphere apply marketing and management techniques originating from business life in order to respond to the challenges coming from the environment and improve their adaption and competition ability.

Hetesi and Veres (2013) classify higher education institutions, as well as public institutions into business actors which meet the demands of the society as part of a complex system. The target group of higher education institutions is wide-ranged. Students who directly use their services, companies who make demands on the labour market, and decision-makers are all customers in this group (Pavluska, 2010). Interpretation of marketing plays a dual part. On the one hand, marketing (especially some of its special fields such as marketing strategy, examination of consumer behaviour, marketing communication) as an external framework deals with higher education as a special case and describes its characteristics. On the other hand, as a technique of marketing activity of universities, it appears as an internal activity and expands from enrolment marketing, image, and communication to improving service quality and increasing the satisfaction of consumers. The model of making a purchase decision has 5 steps, see Figure 2 below.

Figure 2: The model of purchase decision (Kottler-Keller, 2006 p. 265.)

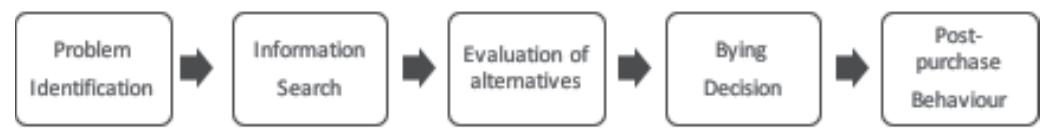

The first step of decision-making is the recognition of the problem. In the case of higher education this need is further education and qualification. The problem is defined in the first step. In the step of information searching, consumers put together data about their purchase. Admission decisions, study guides, open days, education fairs and course-orientation guidance are all important in this section, and the student who wishes to study further has the chance to choose from a wide range of offers at faculties, universities and colleges. Possible options are examined through evaluation and then compared. There is a huge similarity with the previous step: if a student chooses faculty or institution, they need more information about it in order to gain a full perspective. When the same course is available at several universities, it is an interesting question whether the student will choose the course, the university or the city first. Due to the admission process, meaning that the student may apply for more courses, it is unique that it may occur that the student's application will not be successful in enrolling to the first-choice university or course. 
The role of peers has an important influencing ability. The characteristics of consumer behaviour among young people will be pointed out below. When choosing a higher education institution, the individual, the family or even the workplace can be in the position of the decision-maker. Seven special groups of family decisions are distinguished by Töröcsik (2011). In the framework of common decisions, everybody makes their opinions clear and discusses the opportunities in a democratic way, until they finally decide on the purchase on common grounds. This type of decision describes best how further education decisions work as Töröcsik (2010) illustrated it.

Figure 3: Competences of Decisionmakers (Törőcsik, 2010 p. 136.)

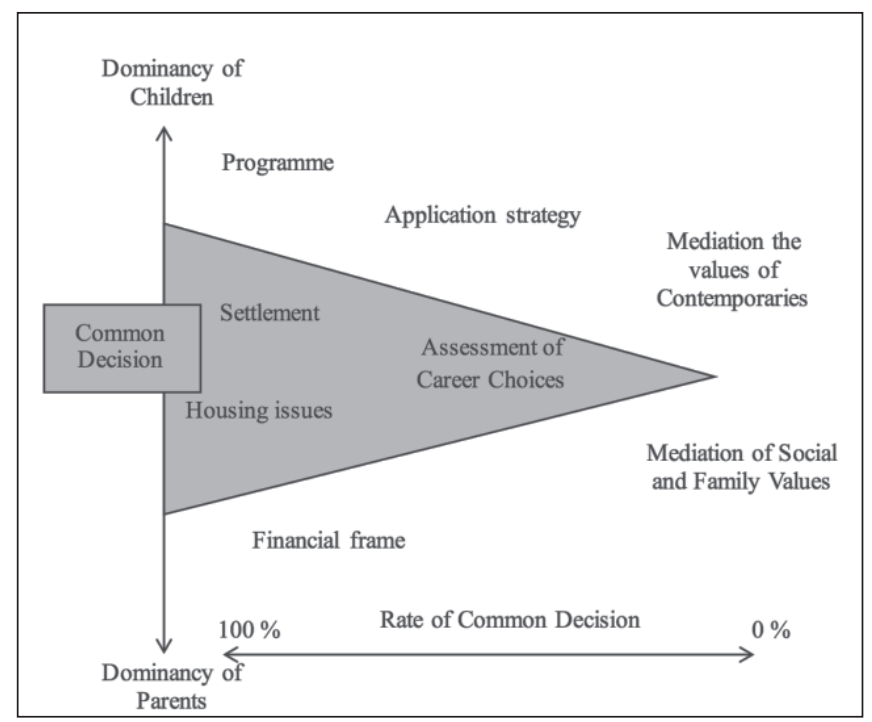

Further education as a purchase decision can be presented by the figure which shows the skills of decision-makers. During the decision-making process of the course and admission strategy, it is clear that the student's opinion has a major role, but in financial matters parents have more power. This obviously is due to the fact that although parents provide more leeway for individual targets and professional interest, they provide the financial ground for education (or its other costs), and therefore they have the final say in financial questions. The children's decision is mainly influenced by the opinion of their peers, while the financial issues are influenced by family values and family matters. Common decisions are made when choosing a city, solving housing issues and discussing ambition possibilities (Töröcsik, 2011).

For a successful marketing process at a university, it is crucial to examine the characteristics of young people and to understand their motivation for further education. Personality and attitude determine motivation to a great extent, but peer opinions also have a great influencing power. 'Motivation is an internal state which moves people who realize single-minded behaviour to achieve determined goals (Bauer-Berács, 1998). Motivation can be divided into primary (instinctive) and secondary (learned) motivation. 
Through their studies people gain a profession and certification, which forms the basis for employment, security, stability and housing. Belonging to a university society, classmates group and a graduate group satisfies the need to belong. The wish for recognition and prestige among higher-level needs can be achieved with the help of a certificate, because a degree means that a person belongs to a higher social group. Self-realisation and the climb to the top of the pyramid can be achieved by higher education. Universities need to become acquainted with the ambitions of the target group, namely the students, in order to provide courses with proper quality and structure, and optimise their admission activity. Furthermore, permanent feedback from current students is also important.

In education, we see $15-20 \%$ of talented students, those performing high above the average, then we see a happy, party-face majority, and another huge group who lives to survive, is seemingly bored or struggles to get a degree and clearly, they have self-evaluation problems too (Töröcsik, 2010).

\section{COMPETITION BETWEEN HUNGARIAN HIGHER EDUCATION INSTITUTIONS}

At the beginning of the 1990s the expansion of higher education started also in Hungary. New colleges and universities were established, the existing institutions extended their training provision, and off-site training courses were launched. With the separation of existing institutions, several new institutions were established. The process created the opportunity of almost unlimited entry by the end of the decade. (Hrubos, 2014) The Act on Higher Education from 1993 introduced the system of normative financing which made the main source of income of institutions dependent on the number of students. Each institution therefore became interested in enrolling as many students as they could. The expenditures of institutions are seen as fixed costs in the short run, and it is hard to draw on a part of them even in the medium run (e.g. the maintenance of buildings, the salary of public servants with permanent status), while incomes depend to the greatest extent on the number of enrolled students. Therefore, all this introduced the term competition to Hungarian higher education. (Rámháp, 2017)

However, due to the current demographic processes, the number of young age groups who serve as a basis for higher education has decreased in the region, including developed countries. The situation is not different in Hungary. Figure 4 presents the decreasing number of high school students in Hungary. 
Figure 4: Number of high school students (in thousand of people) broken down to vocational school, secondary vocational school and secondary grammar school

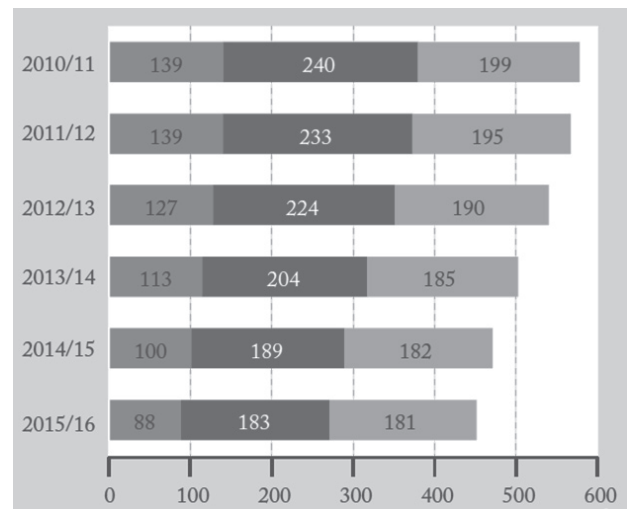

Note: own editing based on the data of Hungarian Central Statistical Office

The Act on Higher Education from 2005 resulted in new levels of education and a new entrance system. Apart from the issues of aging society and the ever-decreasing number of youngsters who form the basis for higher education, a radical change of the regulatory environment brought about the prominence of 'business-like' operation of institutions. In the meantime, the disappearance of national borders for the labour market resulted in international competition. Figure 5 presents the number of applicants to higher education in Hungary.

Figure 5: Number of applications for higher education in Hungary

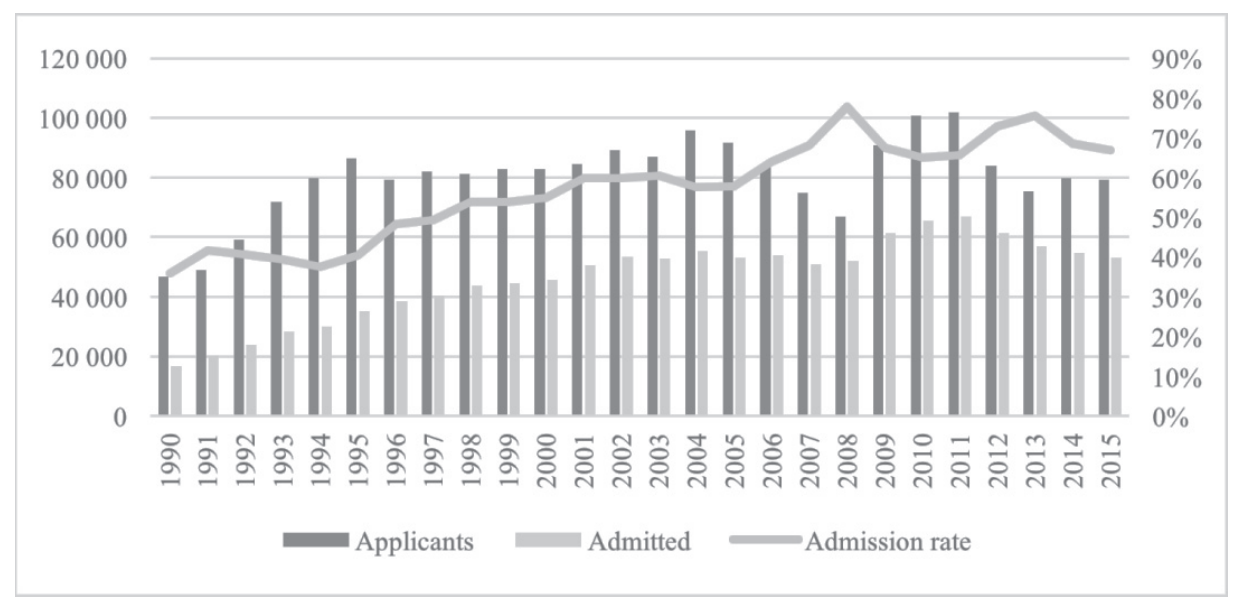

Note: own editing based on the data of Hungarian Central Statistical Office 
The consequence of competitiveness that started in the past decade is that higher education institutions fight for students, state aid and other resources. Because of the decrease in the number of youngsters, institutional closures and mergers, the reduction of state aid, and the limitation of the numbers of potentially admitted students are being discussed in education policy. Figure 6 presents the reduction of educational expenditure in Hungary.

Figure 6: Expenditures on education in Hungary in percentage of GDP

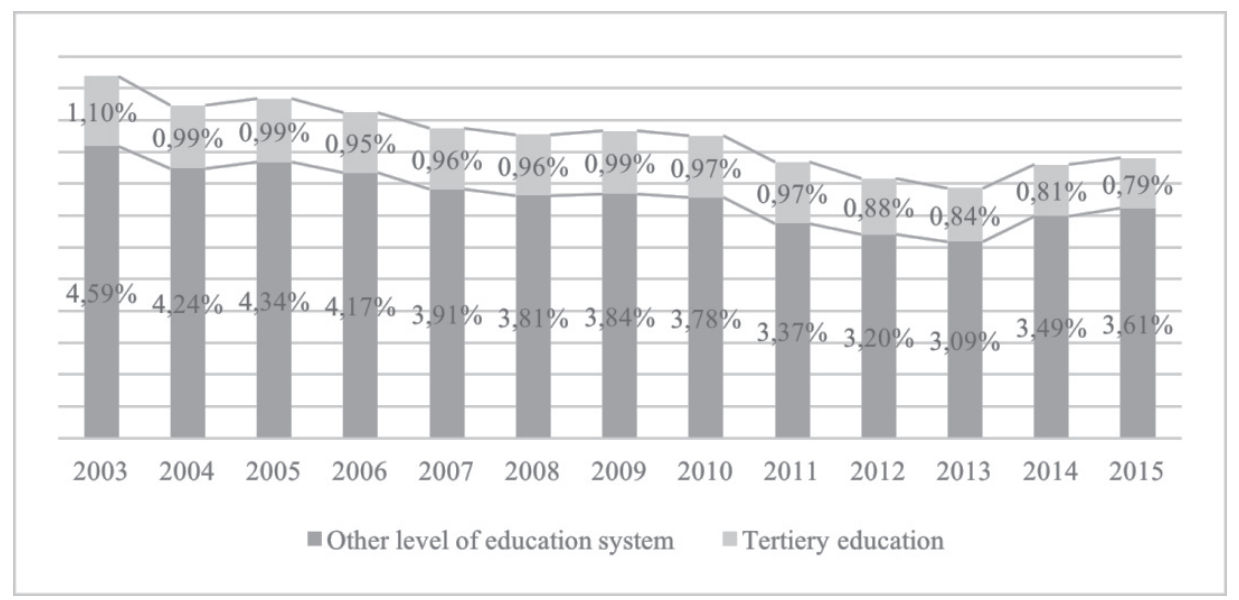

Note: own editing based on the data of Hungarian Central Statistical Office

One of the main objectives of the Bologna Process was to be the harmonisation of higher education and international interoperability. Partly as a result of the domestic break in the process, internationalisation of our higher education failed, although in developing countries, due to the population boom and the widening middle class, there is a huge demand for internationally relevant courses. The increasing intensity of domestic competition was further boosted by the fact that the system was incapable of opening appropriately to developing countries that have excessive training capacities. It was unable to decrease its focus on domestic labour and training market and take advantage of the globalisation of higher education. (Rámháp, 2017)

The Hungarian higher education system therefore faces several challenges having as a consequence the start of the marketization processes, a change in basic institutional structures and operation models, in which the role of marketing is valued more.

\section{THE PURPOSE AND METHODOLOGY OF EMPIRICAL RESEARCH}

However, marketing activity has not advanced to a strategic level in higher education in Hungary, and this is a serious problem. Marketing experts are not involved in decision-making, and there is no real marketing strategy. Substantive progress can 
be mostly seen in the development of communication and the establishment of alumni systems. (Kuráth - Töröcsik, 2011)

In addition to motivational analyses and career monitoring systems, the analyses of career choice motivation of young people for admission to higher education should be integrated into broad strategic planning. This is the third basis of planning information inputs.

The aim of the research is to reveal and introduce career choice motivation of domestic secondary school students, with a special emphasis on the students studying in the industrial region of Györ, by analysing the effects of the region's economic and social structures on career choice motivation.

Regarding the region, the Employment Strategy of Györ-Moson-Sopron County stated that financially strong multinational companies present in the region and related small and medium-sized enterprises created a strong economic base, a good work environment which fostered a positive attitude of workers. According to the Strategy, the region is characterized by a wide offer of training programs, a differentiated system of institutions and parents, students, teachers and economic actors whose motivation is above average in the country. Furthermore, it is important that the key stakeholders of the region identified the absence of technicians (who do not need an academic degree) as a barrier to economic development. Shortage of labour, which differs according to sector, increased the level of revenues that could be earned without a diploma. (Strategy on Employment of Györ-Moson-Sopron County, 2016)

During our empirical research, we dealt with the main enrolment area of Széchenyi István University in Györ. Although the university attracts students from the whole country, it is mainly attractive to the students from two NUTS 2 regions, namely the West-Transdanubia and the North-Transdanubia region. During the research, we conducted a questionnaire survey in the secondary education institutions of the area among students who are about to apply to a higher education institution. We conducted a cross-sectional research including six counties in two phases. First we aimed at surveying 2000 students in 2012, and we repeated the survey in 2015 and this time the aim was to survey 800 students. During the selection of 30 institutions for the sample, we took into consideration all secondary schools in the area.

To get the necessary data we used a questionnaire that could be completed in maximum 20 minutes, and students filled it in independently at the high school under supervision. The types of questions used in the questionnaire were as follows: measuring agreement with statements regarding attitudes and preferences in a 5-point, not-compelling Likert-type scale in a tabular format per question.

The questionnaire consisted of four main parts.

1. Measurement of preferences regarding further education and career choice:

a. identification of information sources and affecting factors

b. measurement of attitudes regarding training areas

c. identification and measurement of the power of information sources regarding further education in higher education, selection of course and institution. 
2. Measurement of the assessment of Széchenyi István University and that of other determining institutions of the region.

3. Measurement of attitudes toward Széchenyi István University with regard to the type of the education and the courses.

4. Demographic questions to identify the target group.

\section{THE RESULTS OF EMPIRICAL RESEARCH}

Based on our survey, 70.4\% (2012) and 70.8\% (2015) of the respondents plan to study further. The rate of further education is the highest (above 90\%) in special 6-8 grade high schools. In case of traditional 4-grade high schools this rate is about $80 \%$ and it is the lowest, almost $60 \%$ in vocational schools which provide a profession beside a general certificate of education. The highest level of education of parents, especially of the father, is a determining factor in case of further education motivation. The result of Crosstab analysis shows that a higher rate of those students whose parents have higher levels of education plan to study further, which is also proved by the $\chi^{2}$ test [Chi-square test]. Likewise, similar correlation can be found between the assessment of the family's financial status and the intent to study further. Namely, those who live in better financial conditions plan to study further to a greater extent. Among those students who consider their financial status much worse than the average, the rate of intention to study further continued to fall (53\%) in the survey from 2015 compared to that from 2012 (68\%). We measured the motivation of those students who do not want to study further by asking them to agree with attitude statements with the help of a 5-point Likert-type scale:

- I have better employment opportunities in my profession

- I can earn more money with my profession

- I can expect better working conditions by working in my profession

- I do not have appropriate scholastic records for that

- I am afraid of not meeting the requirements of higher education

- my financial resources do not permit me to do so

- my family does not support it

- I would like to start a family as soon as possible

- I would like to work and build a career abroad

We conducted a factor analysis in the group of these variables, during which we conducted rotated main component analysis based on Varimax-method, the pertinence of which was controlled by KMO indicator. We defined the following complex variables:

1. Better employment opportunities in the profession, better opportunities for earning money and better working conditions belong to the first factor. This is the professional aspects decision factor. 
2. Inappropriate scholastic records, non-compliance with the requirements, inappropriate financial status and the lack of familial support belong to the second factor. This is fear decision factor.

3. Early family formation and the opportunity to work abroad belong to the third factor. This is social and financial security decision factor.

After analysing the selection of the courses, it was revealed that the majority of students choose a course based on future employment opportunities and expected salaries. As for the direction of further education, if we compare the national data with the regional, we can see that the labour market specialties of the area appear as subjects of the courses selected by the students. Figure 7 shows this.

Figure 7: Chosen career areas in percentage of the respondents (2015)

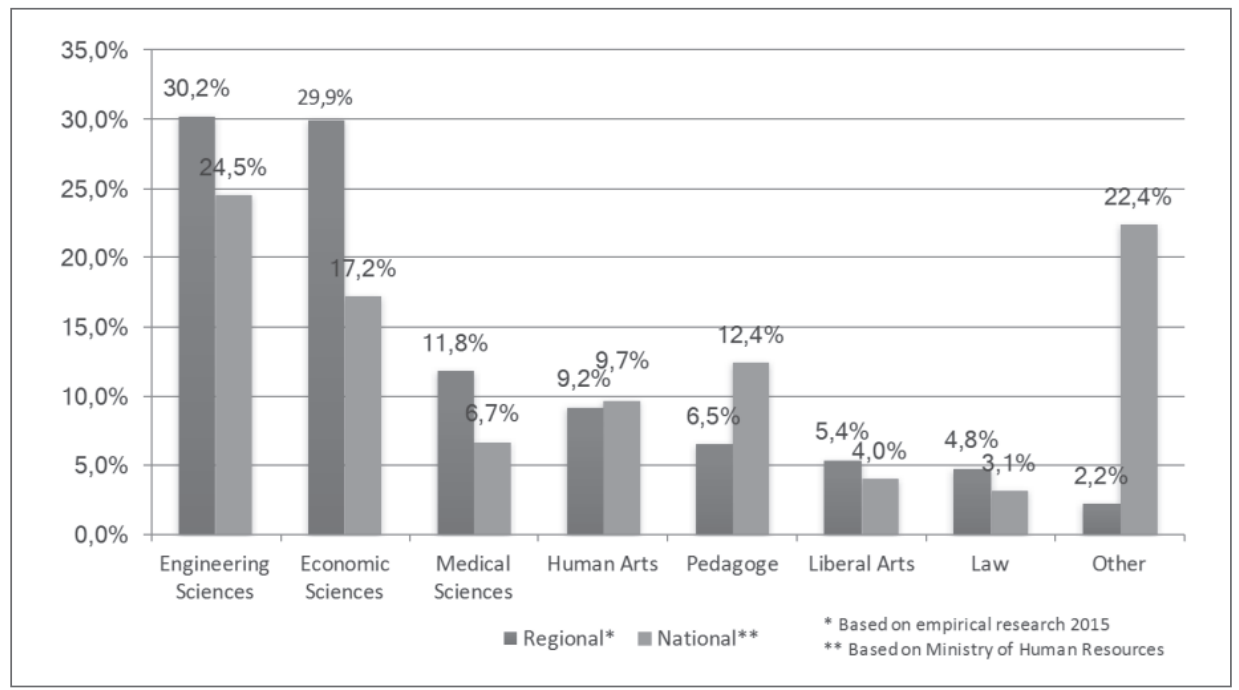

Source: Authors'work

During the survey, we examined the motivation of the target group regarding the selection of the higher education institution. We measured their agreement with 11 attitude statements on a 5-point Likert-type scale. These attitudes are as follows:

- proximity

- prestige

- assessment by companies

- dormitories

- quality of professional, scientific trainings

- lecturers 
- student organisations

- sport and leisure facilities

- campus infrastructure

- place in rankings

- international relations.

We conducted a hierarchic cluster analysis on a group of variables affecting the selection of the higher education institution. We applied the Ward-method during the analysis and the discriminant analysis to interpret clusters. We defined the following four clusters:

1.The quality of the professional/scientific training of the institution, the lecturers and the institution's prestige are highly important to respondents belonging to the first cluster. In contrast to this, the institution's proximity, its dormitories and student organisations or the sport and leisure facilities are not important to them at all. They are the group of quality-oriented respondents.

2.On the contrary, the institution's sport and leisure facilities, its dormitories and international relations are the most important for those belonging to the second cluster, while proximity, quality, assessment by companies and prestige are not important for them. They are the group of self-fulfilling respondents.

3.In the case of those belonging to the third cluster, all average values are very low compared to other clusters. The institution's prestige, its lecturers and professional/ scientific quality have especially low values. They are the group of indifferent respondents.

4.In the case of those belonging to the fourth cluster, the institution's proximity, its dormitories, sport and leisure facilities and its student organisations are the most important. The institution's international relations, its prestige, lecturers and the training's quality are not important at all. In the case of those belonging to this cluster the accessibility and availability of the training as well as belonging to a community dominate, thus they are the group of those demanding social/financial security.

These clusters may be of help in the segmentation of students who are about to sit for an entrance exam, in more effectively addressing their needs for services, and in developing marketing communication, namely what to communicate to each group.

An important and determining element of career choice is the assessment of income position related to a given profession. In Hungary, several national surveys analysing the career path of youngsters have already showed that students have excessive income expectations from their future employers (Deloitte 2015; GfK 2015). During our survey, we experienced that the students of the industrially more developed area have a more realistic career path - which we can also see with regard to their income expectations as shown by Figure 8 . 
Figure 8: Expected monthly gross wage of respondents after obraining their degree

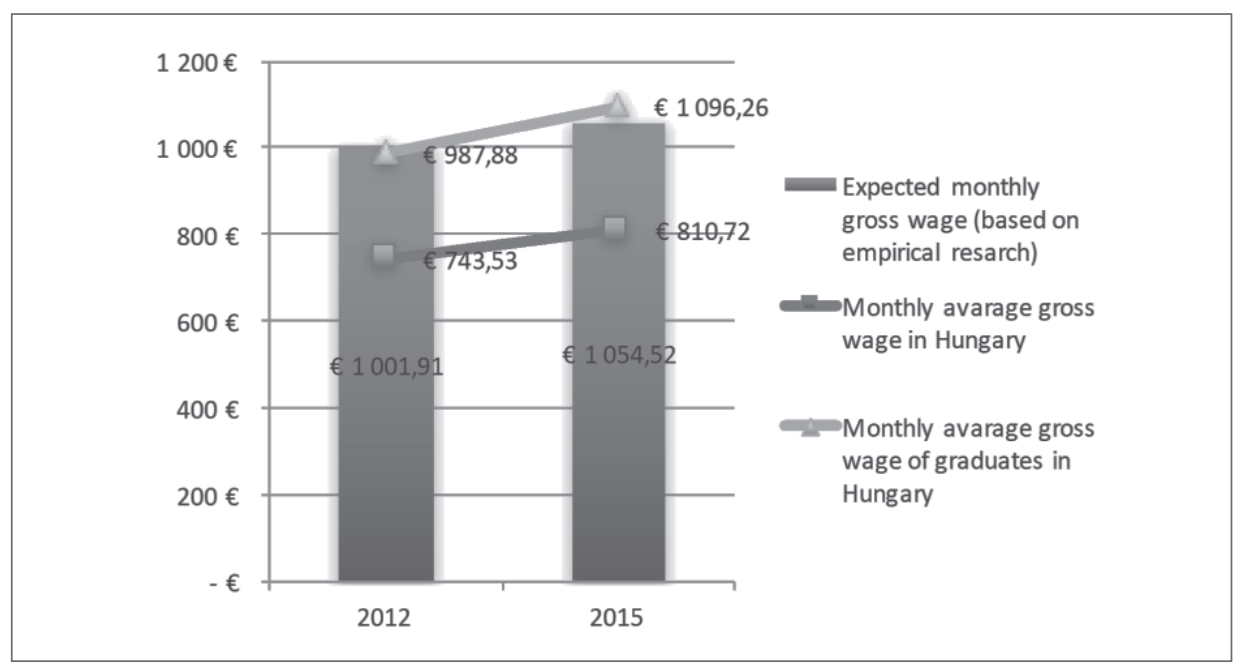

Source: Authors' work

\section{CONCLUSION}

With the transformation of the service systems comes the change in the institutional frameworks of education and training, and this requires a novel approach. The labour market demands of the knowledge economy have drastically changed in the past two decades. The role of education has been upvalued and the higher education system has to face new challenges.

Due to the population processes of the developed world, the number of young people in the country is decreasing, which in turn is influencing the decrease in the domestic source of institutions. In this situation the demand for higher education has an outstanding importance, more specifically, it is important to have an accurate knowledge of career choice motivation of secondary school leavers.

The novel results of our empirical research are as follows:

1. Our survey proved that complex decision variables are in the background of deciding on further higher education. Those who do not want to participate in higher education form a heterogeneous group, and two factors appear in their decisions: on the one hand, there are fears of further education (bad scholastic records, inappropriate financial conditions, the lack of familial support), an on the other hand, there is a positive picture of the future when one has a profession.

2. It was also verified that students choosing their further education form a heterogeneous group based on their preferences for the selection of courses and institutions, and their ideas about future. By knowing these demands and with the help of cluster analysis we can classify the secondary school students who are about to enter higher education, namely we can segment the primary 
consumer market of higher education institutions. With regard to the analysed area, it can be stated that students make their decisions based on employment opportunities and expected salaries on the current labour market.

3. It was proved that there are no 'best practices' that can be applied to the organisation of enrolment activity of higher education institutions. Every institution has to develop its own 'good practices' in line with the specific regional conditions.

4. Because the data of the surveys of 2012 and 2015 enabled a time series analysis, we were successful in revealing that the career choice preferences of the examined target group barely changed during this period of three years despite the fact that during this period changes affected the entrance system, and there were institutional realignments as well as integrations. Therefore, it can be concluded that the transformation of higher education at any level, as well as the modifications in career orientation systems are long-term processes, and their effect is negligible a few years ahead.

\section{REFERENCES:}

1. Barakonyi Károly (2010): Új egyetemi kihívások. In: Törőcsik Mária - Kuráth Gabriella (ed.): Egyetemi marketing. Marketing a felsőoktatásban. Pécs, Pécsi Tudományegyetem. pp.9-22.

2. Carayannis, E. G. - Barth, T. D. - Campbell, D. F. (2012): The Quintuple Helix innovation model: global warming as a challenge and driver for innovation. Journal of Innovation and Entrepreneurship, 1:2, pp. 1-12.

3. Carayannis, E. G. - Campbell, D. F. (2012): Mode 3 knowledge production in quadruple helix innovation systems. Springer, Berlin, pp. 1-63.

4. Deloitte (2015): A frissdiplomásoknak már nem a magas bér a legvonzóbb. Retrived from: http://www2.deloitte.com/hu/hu/pages/karrier/articles/first-steps-sajto-2015.html (2016. 03. 20.)

5. Etzkowitz, Henry - Leydesdorff, Loet (2000) The dynamics of innovation: from National Systems and „MODE 2" to a Triple Helix of university-industrygovernment relations. In: Research Policy, vol. 29. no. 2. pp. 109-123.

6. Filep Bálint., Kovács Zsolt, Tamándl László (2010): Észak-dunántúli vállalkozói elit elvárásai a Széchenyi István Egyetemmel és hallgatóival szemben. Tér ÉS Társadalom Vol. 24., No.2., pp. 93-105.

7. GfK Hungária Piackutató Intézetet (2015): Provident Családi Kassza Index 2015. Retrived from: https://www.provident.hu/kapcsolat/sajtoszoba/provident-csaladi-kassza-index-2015 (2015. december 10.)

8. Hetesi Erzsébet, Veres Zoltán (2013). Nonbusiness marketing. Budapest, Akadémiai Kiadó. 
9. Hrubos Ildikó (2014): Expanzió - határok nélkül. In Educatio 2014/2. pp 205-215. Budapest, Educatio Nonprofit Kft.

10. Kotler, Philipp - Keller, Kevin Lane (2006): Marketingmenedzsment. Budapest, Akadémiai Kiadó.

11. Lengyel Imre (2004): The Pyramid Model: Enhancing Regional Competitiveness in Hungary. Acta Oeconomica, Vol 54., No. 3., pp. 323-342.

12. Trow, Martin (2000): From Mass Higher Education to Universal Access. e American Advantage. University of California, Berkeley

13. Pavluska Valéria (2010): A marketingelmélet új irányai a felsőoktatási marketing megalapozásában. In: Törőcsik Mária - Kuráth Gabriella (ed.): Egyetemi marketing. Marketing a felsőoktatásban. pp. 65-82. Pécs, Pécsi Tudományegyetem.

14. Rámháp Szabolcs (2017): Felsőoktatási továbbtanulási motivációk Magyarországon a változó ifjúság és a piacosodó felsőoktatás tükrében. Doktori értekezés. Széchenyi István Egyetem, Györ.

15. Törőcsik Mária (2010): Fiatalok fogyasztói magatartása. In: Törőcsik Mária Kuráth Gabriella (ed.): Egyetemi marketing. Marketing a felsőoktatásban. pp. 123141. Pécs, Pécsi Tudományegyetem.

16. Törőcsik Mária (2011): Fogyasztói magatartástrendek, vásárlók. Budapest, Akadémiai Kiadó.

17. Strategy on Employment of Győr-Moson-Sopron County (2016), Retrived from: http://www.gymsmo.hu/article/gy-m-s-megyei-foglalkoztatasi-paktumiroda.html (2017.05.20) 


\title{
MOTIVACIJA ZA IZBOR ZANIMANJA MEĐU SREDNJOŠKOLCIMA U KONTEKSTU VISOKOŠKOLSKOG OBRAZOVANJA U GOSPODARSTVU ZNANJA *
}

\author{
Szabolcs Rámháp ${ }^{6}$, Dávid Nagy $^{7}$, Ákos Országh ${ }^{8}$, János Rechnitzer $^{9}$ \& Bálint Filep ${ }^{10}$
}

\section{Sažetak}

U 21. stoljeću došlo je do drastičnih socijalnih i gospodarskih promjena: započelo je razdoblje gospodarstva znanja. Zbog sve većeg značaja znanja, promijenila se i priroda znanja kao i očekivanja koja imamo od njega. Tradicionalni pristup u srednjoškolskom i visokom obrazovanju ne može zadovoljiti potrebe za kvalifikacijama u strateškim industrijama. Obrazovne institucije koje se bave stvaranjem znanja i njezinim iskorištavanjem, širenjem i reprodukcijom postali su podloga za društvo utemeljeno na znanju. Danas se uloga i zadaće visokoobrazovnih institucija ponovno ocjenjuju u cijeloj Europi, što će dovesti do novih pristupa u ekonomskim i socijalnim ulogama i projektima. Sveučilišta daju temeljni doprinos stvaranju i prilagodbi ljudskih resursa, a njihova uloga raste na regionalnoj razini. Visoko se cijeni uloga koju imaju visokoobrazovne institucije u potpori regionalnom upravljanju.

Naše istraživanje usredotočuje se na karijernu motivaciju srednjoškolaca u sjevernom dijelu Zapadnog Podunavlja Mađarske, koje je najvažnije industrijsko središte u zemlji i središte mađarske automobilske industrije. Rad se temelji na anketi provedenoj među 2000 ispitanika. Njihova osobna motivacija određuje opstanak ustanova visokog obrazovanja u sve jačoj konkurenciji, a može utjecati i na poboljšanje regionalne konkurentnosti. Istraživanje je upotrijebilo neke statističke metode poput određivanje frekvencija i prosjeka, tablicu frekvencija, analizu varijance te faktorsku i klaster analizu.

Glavni cilj istraživanja je istaknuti vezu između visokog obrazovanja i regionalnog gospodarstva kroz primjer industrijske regije Đura (Jura) te pokazati kako kvalitetna industrija u gospodarstvu znanja može utjecati na karijernu motivaciju mladih ljudi prilikom biranja područja budućeg obrazovanja, te odrediti njihova očekivanja u pogledu mogućnosti zapošljavanja i budućeg prihoda na tržištu rada u budućnosti, kao i bi li umjesto toga odabrali iseljavanje.

Ključne riječi: motivacija za izbor zanimanja, srednjoškolski učenici, gospodarstvo znanja, sjeverni dio Zapadnog Podunavlja, Mađarska.

\section{JEL klasifikacija: I23, I25}

\footnotetext{
Rad je prezentiran na 2. Međunarodnoj konferenciji „Business \& Entrepreneurial Economics-BEE2017” koja je održana na Brijunima od 24. do 26. svibnja 2017. godine (www.bee-conference.com)

6 Szabolcs Rámháp, doktorand, Sveučilište Széchenyi István, Doktorski studij regionalnih i ekonomskih znanosti, Győr, Mađarska, E-mail: ramhap@sze.hu

7 Dávid Nagy, student doktorskih studija, Sveučilište Széchenyi István, Doktorski studij regionalnih i ekonomskih znanosti, Győr, Mađarska, E-mail: nagy.david@ga.sze.hu

8 Ákos Országh, student doktorskih studija, Sveučilište Széchenyi István, Doktorski studij regionalnih i ekonomskih znanosti, Győr, Mađarska, E-mail: orszakos@gmail.com

9 Dr. sc. János Rechnitzer, mentor za doktorsku disertaciju, profesor i predstojnik katedre, Katedra za regionalne studije i javne politike, Széchenyi István University, Győr, Mađarska, E-mail: rechnj@sze.hu

10 Dr. sc. Bálint Filep, izvanredni profesor, mentor za doktorsku disertaciju, Katedra za regionalne studije i javne politike, Széchenyi István University, Győr,Mađarska, E-mail: filep.balint@sze.hu
} 